Summer 2006

\title{
Challenges for Private Sector Conservation: Sanderson's The Future of Conservation in Tierra del Fuego
}

Julia Amrock

Indiana University School of Law

Follow this and additional works at: https://www.repository.law.indiana.edu/ijgls

Part of the Environmental Law Commons, and the International Law Commons

\section{Recommended Citation}

Amrock, Julia (2006) "Challenges for Private Sector Conservation: Sanderson's The Future of Conservation in Tierra del Fuego," Indiana Journal of Global Legal Studies: Vol. 13 : Iss. 2 , Article 11. Available at: https://www.repository.law.indiana.edu/ijgls/vol13/iss2/11

This Note is brought to you for free and open access by the Law School Journals at Digital Repository @ Maurer Law. It has been accepted for inclusion in Indiana Journal of Global Legal Studies by an authorized editor of Digital Repository @ Maurer Law. For more information, please contact rvaughan@indiana.edu.

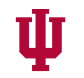

JEROME HALL LAW LIBRARY

INDIANA UNIVERSITY

Maurer School of Law
Blooming ton 


\title{
Challenges for Private Sector Conservation: Sanderson's The Future of Conservation in Tierra del Fuego
}

\author{
Julia Amrock*
}

Abstract

To date, global protection of biodiversity has been largely dominated by governmental actors. Ecosystems transcending state boundaries find themselves at the mercy of international agreements, for better or for worse. Steven Sanderson of the Wildlife Conservation Society (WCS) suggested for worse in The Future of Conservation, but he gave hope for more effective environmental conservation, if the private sector could gain more standing globally. The plan that Sanderson created for self-assertion of nongovernmental environmental groups describes approaches typically endorsed not by NGOs but by governments: global alliances, political strategy, human-centered conservation, and economic development. This Note isolates the current use of these strategies by NGOs or in private environmental preserves and examines their efficacy for successful conservation, and finds Sanderson's argument to have merit. NGOs are employing these concepts in environmental management and successfully overcoming some private sector pitfalls.

A new, privately owned preserve in Tierra del Fuego provides an ideal forum for comprehensive implementation of Sanderson's plan-and the WCS has discretion to manage the land accordingly. Ultimately, I predict successful conservation here, based on strategies previously advocated by its managing organization.

\section{INTRODUCTION}

In September 2002, Dr. Steven Sanderson, President and Chief Executive Officer of the Wildlife Conservation Society (WCS), published a brief essay in the Journal of Foreign Affairs entitled: The Future of Conservation. ${ }^{1}$ Its primary mission was to advocate the need for more nongovernmental involvement in the

*J.D., 2006, Indiana University School of Law-Bloomington; B.S., Biology, 2003, University of Alabama. I would like to thank Professor Robert Fischman for his inspiration and guidance throughout the composition of this Note.

1. Steven Sanderson, The Future of Conservation, J. Foreign Afr., Sept./Oct. 2002, at 162. 
ongoing global efforts to preserve biodiversity. ${ }^{2}$ Sanderson alleged that "the international institutions charged with Earth's care [were] not managing it with an eye on 'sustainability"' 3 and provided that the increasing problem of biodiversity depletion would require "strategies in the private sector to rescue conservation from development and poverty alleviation from ecological degradation." Perhaps to dissuade a more easily palatable view of his writing as purely theoretical and lacking in necessary implementation methods, Sanderson included a specific sequence of focus points for "A New Conservation Agenda"-a checklist for effective management by the WCS and its colleagues. ${ }^{5}$ Conveniently, in September 2004, the WCS was presented with an opportunity to comprehensively test this plan when the Goldman Sachs Charitable Fund donated 680,000 acres of land in Tierra del Fuego, Chile, to the WCS for conservation management. ${ }^{6}$ Such a generous and unprecedented grant provides an opportunity for evaluating the practicality and efficacy of Sanderson's proposal, as his own corporation will retain complete control of the land and its environment. ${ }^{\text {? }}$

Sanderson's essay is essentially a response to government's inability to protect the environment against the economic expansion associated with global-

2. Biodiversity is defined as "diversity, or variety, in the living things in a particular area or region," and is used here to refer to biological diversity on a global scale. WEBster's NEw WorLd College Dictionary 140 (3d ed. 1986). World-renowned biologist E.O. Wilson brilliantly describes the evolution of global diversity in The Diversity of Life. Edward O. Wilson, The DiverSitY of LifE (New ed. 1999).

3. Sanderson, supra note 1 , at 162.

4. Id.

5. Sanderson predicted that future conservation efforts in the private sector would involve the following elements: "It]he politics of place," or attention to geographical areas of human poverty as well as biological significance; "[w]ildlife health surveillance" on a global scale; "[t]racking the state of the wild," and informing society of such; "[s]cientific sustainability audits" to assess the effects of human development on the biosphere; "[t]he protection of global heritage"; financially "[e]ndowing conservation rather than governments"; "[m]ainstreaming the Convention on Biodiversity"; "[c]reating global conservation alliances" of various organizations; and a "conservation code of conduct" for businesses and industries. Id. at 169-73.

6. See Larry Rohter, Preserving an Old-Forest Wildemess at the Ends of the Earth, N.Y. TIMEs, Sept. 14, 2004, at F3.

7. Id. 
ization. ${ }^{8}$ Yet, his answer is not simply to force more nongovernmental organizations (NGOs) onto the scene, but to command a new overall focus in the nongovernmental sector: one that actually takes up the approaches of concededly ineffective or unacceptable governmental efforts and allows private sector skills to improve their application. Particularly, he advocates the creation of global conservation alliances among NGOs, ${ }^{9}$ human-centered, scientific management, ${ }^{10}$ and a public sector brand of sustainable development. ${ }^{11}$ These strategies blend private sector fortes with public sector priorities, a combination already reflected in some successful NGOs' management efforts. '"

This Note seeks to appraise Sanderson's proposal in The Future of Conservation-in light of past corporate and other exclusively nongovernmental conservation efforts-as an actual system of environmental conservation rather than a dismissible reinforcement of the WCS and the implied necessity of its cause. By applying Sanderson's criticism to the private, rather than public, sector, his theory becomes a realistically quantifiable solution. Though not entirely novel, his plan is not apologetic and, as this paper will conclude, is convincingly viable for the future. With the Tierra del Fuego project as a concrete embodiment of Sanderson's plan, The Future of Conservation can be contrasted with typical objectives of private environmental groups and presented as a fresh solution to their misguidance, as well as the inefficacy of previous governmental endeavors.

This analysis will first explore the facets of Sanderson's argument and identify the important elements of biological conservation in his proposal. Second, this Note will examine the WCS's acquisition of the new wildlife reserve in Tierra del

8. Sanderson expounds:

As the world grows economically richer, it is becoming biologically poorer.

... Economic expansion, population growth, urbanization, and development lead to greater consumption. In turn, growing consumer demand fires competition for fresh water, energy, arable land, forest products, and fish. And globalized production permits the harvesting of nature at ever more rapid rates.

Sanderson, supra note 1 , at 163.

9. Id. at 172 .

10. Id. at 169-71.

11. Id. at 168 .

12. An example is the promotion of sustainable development in Costa Rica. See Michael Sturm, The Mixed Experience of Private Sector Involvement in Biodiversity Management in Costa Rica, in Biodiversity, Sustainability and Human Communities 243 (Tim O'Riordan \& Susanne StollKleemann eds., 2002). As discussed below, Costa Rica is noted for its high level of private sector environmental conservation, which employs ecotourism and participatory management to preserve biodiversity in this region. See generally id. 
Fuego and its posture as a suitable paradigm of the New Conservation Agenda. Though the conservation plan for these lands remains incomplete, this paper assumes the projected strategies to be representative of Sanderson's ideal. Finally, this Note will evaluate, through comparison with other private sector management schemes as well as secondary literature, the key elements of Sanderson's argument and the major strategies he suggests for NGOs, including interactions with government and globalization, choice of location, and incorporation of science and education in the implementation of sustainable development.

\section{A New Conservation Agenda for the Private Sector: The Future of Conservation According to Steven Sanderson}

Sanderson begins his essay by engaging in the traditional rhetoric of his field concerning the growing depletion of global biodiversity. ${ }^{13}$ By subsequently recounting the "road from Rio," $1+$ or the sordid history of international environmental law, he places at least a portion of the responsibility for declining biodversity on the politics and misplaced priorities of international political entities. ${ }^{15} \mathrm{His}$ next move proves somewhat less predictable, as he describes the New Conservation Agenda ${ }^{16}$ for the private sector, which involves not a refocus on species and the environment-placed squarely over human concerns of development-but rather an actual commitment to anthropocentrism ${ }^{17}$ and globalization, ${ }^{18}$ which provide a background for his purportedly effective ecological conservation strategy. This particular focus, along with the specificity of his hypothesis, provides a tangible foundation to analyze his ideas by means of comparison.

Specifically, Sanderson's plan defines some critical aspects of conservation and land management, which are presumed in this paper to be the goals of the WCS itself in its future projects as an environmental NGO. First, conservation efforts should focus on the rural poor, ${ }^{19}$ and allow environmental concerns to be

13. Sanderson, supra note 1 , at 162.

14. Id. at $163-66$.

15. Id. at $165-66$.

16. Id. at $169-73$.

17. Tal Scriven defines anthropocentrism as "approach[ing] the issues of pollution, overpopulation, and other forms of ecological degradation in terms of human interests." TAL Scriven, Wrongness, Wisdom, and Wilderness: Toward a Libertarian Theory of Ethics and the ENvironMENT 147 (1997). For more on the difference between anthropocentrism and ecocentrism, see generally $i d$. at 147-49.

18. Sanderson, supra note 1, at 169-71.

19. Id. at $168-70,173$. 
addressed through implementation of sustainable development. ${ }^{21}$ Similarly, he advocates the importance of local involvement in conservation management. ${ }^{21}$ Sanderson proposes continuous scientific surveillance, ${ }^{22}$ and recommends interorganizational alliances to comprehensively implement this data. ${ }^{23} \mathrm{He}$ also stresses the need to protect the cultural heritage of the people living in areas of conservation management. ${ }^{2+}$ Identification of specific and unique ecosystems for special protection, as demonstrated by the World Heritage sites, will enhance the overall level of preservation of global biodiversity. ${ }^{25}$

\section{Implementing This Plan in Tierra del Fuego, Chile}

Two years after Sanderson proclaimed his conservation agenda, the Goldman Sachs Charitable Fund donated 680,000 acres of Chilean land in Tierra del Fuego to the WCS for environmental protection. ${ }^{26}$ Goldman Sachs acquired this land, approximately one-third the size of Yellowstone National Park, in 2003 as part of a legal settlement with the Trillium Corporation, a real estate- and forestry-management company based in the Pacific Northwest. ${ }^{27}$ Trillium had planned to establish a logging operation on the island, but Goldman Sachs, a leading global investment-banking firm, decided to protect the land's extensive old-growth forests. ${ }^{28}$ Goldman Sachs chose the WCS to manage the land based on its extensive conservation activities in the "Southern Cone" of South Amer-

20. Debate over the definition of sustainable development indicates its controversial stature in environmental preservation. See Robert W. Kates et al., What is Sustainable Development: Goals, Indicators, Values, and Practice, Environment, Apr. 2005, at 8 . Sanderson uses this term to mean the ability to "connect short-term human betterment with conservation for long-term sustainability." Sanderson, supra note 1 , at 168 . Rather than simply fighting for the long-term conservation side of this balance, Sanderson wants NGOs to teach governments how to implement sustainable development and "show how poverty can be alleviated with minimal additional damage to wild places and wild creatures." Id. at 168-69.

21. Id. at 169.

22. Id. at 170-71.

23. Id. at 172 .

24. Id. at 171 .

25. Id.

26. See Rohter, supra note 6.

27. See Press Release, Wildlife Conservation Society, Goldman Sachs Announces Transfer of Unique Chilean Wilderness to WCS (Sept. 14, 2004), http://www.wcs.org/353624/4556203. For information about Trillium's activities and objectives, see generally http://www.trilliumcorp.com/ trillium.html.

28. Press Release, Wildlife Conservation Society, supra note 27, at 2. 
ica, as well as its reputation for being committed to long-term involvement ${ }^{29}$ and for working with local people to find solutions to conservation issues. ${ }^{30}$

The WCS has been working in Latin America since the early 1900s and in the Southern Cone since the $1960 \mathrm{~s} .{ }^{31}$ It recently helped to develop the Patagonia Coastal Zone Management Plan, and it works with Chilean organizations in Bernando O'Higgins National Park. ${ }^{32}$ The new reserve is located in the Chilean portion of Tierra del Fuego, on the western edge of the island; the island's eastern edge belongs to Argentina. ${ }^{33}$ Tierra del Fuego is separated from the mainland of South America by the Straits of Magellan, named after the explorer who visited in 1520 and gave the island its name, officially the Isla Grande de Tierra del Fuego ("Land of Fire"). ${ }^{3+}$ To the south, across the Seno Almirantazgo, is a range of snow-capped mountains, the Darwin Range, which contains the Marinelli Glacier. ${ }^{35}$ Charles Darwin visited the island while traveling aboard the H.M.S. Beagle and wrote about its native people and its wildlife. ${ }^{36}$

The "comprehensive conservation strategy" for the reserve is currently being drafted, and information from the WCS administrators as to specifics of the plan is difficult to obtain. Chileans themselves will advise and collaborate in this strategy, and they will be involved with the administration of the reserve through participation in a local advisory board, consisting of mostly Chilean citizens, such as scientists, conservationists, government officials, and business leaders. ${ }^{3 \bar{T}}$ The WCS has made no mention in its press releases of specific involvement from the sheep farmers and cattle ranchers who inhabit the island..$^{38}$ However, the WCS plans to employ sustainable development techniques, including ecotourism, "[w]henever possible" for the benefit of local people and communities. ${ }^{39}$

29. Id. at 3 .

30. Id.

31. Id.

32. Id.

33. Rohter, supra note 6.

34. Press Release, Wildlife Conservation Society, supra note 27, at 2.

35. Rohter, supra note 6.

36. Press Release, Wildlife Conservation Society, supra note 27, at 2.

37. Id.

38. Rohter, supra note 6.

39. Press Release, Wildlife Conservation Society, supra note 27, at 4. 


\section{Evaluating Sanderson's Strategy by Comparison and Analysis}

\section{A. "Political Boundaries" and Globalization}

\section{Cooperation with Local Governments}

The Future of Conservation champions increased private actor participation in environmental conservation globally, suggesting an overarching insufficiency in biodiversity management through state action and international treaties. ${ }^{40}$ Sanderson includes individuals, companies, civic institutions, and other NGOs in this revered private sector, and charges that they have been kept out of the conservation movement due to a lack of political power, in spite of the valuable resources and perspectives they possess. ${ }^{+1}$ In lamenting the overall decline of species as well as ecosystems, Sanderson attributes the increasing loss of biodiversity in part to this public-private separation and the idea that "nature and science do not fit within political boundaries." monly held conclusion that NGOs can be more effective than governments in protecting the environment because they are not political, or, more precisely, because they are not corrupted by political concerns. ${ }^{43}$

But this assumption is not entirely accurate; private actors, especially corporations, are often highly influenced by politics, sometimes at the expense of environmental integrity. ${ }^{44}$ Sanderson claims that private conservation organizations "demand transparency in the public policy debate," 45 yet often the funding for such organizations hinges on their ability to appease political and economic entities. Mac Chapin, in A Challenge to Conservationists, asserts that "[t]he conservationist NGOs are no longer able to openly oppose government corruption or inaction, which is often the primary cause of environmental degradation in countries of the Third World; government backing of extractive industries in fragile forest areas is one of the most common outcomes. ${ }^{46}$ Thus, the unadulterated ide-

40. Sanderson, supra note 1 , at 166.

41. Id. at $166-67$.

42. Id. at 166 .

43. See id. at 165.

44. See Ione Egler, Brazil: Selling Biodiversity with Local Livelihoods, in Brodiversity, Sustainability and Human Communities, supra note 12, at 210, 225-26.

45. Sanderson, supra note 1 , at 167.

46. Mac Chapin, A Challenge to Conservationists, in World Watch: Vision for a Sustainable WORLD 17, 25-26 (2004). 
als of environmental NGOs may yield to means of self-preservation through cooperation with environmentally successful state and private actors. Chapin states further:

National governments-and the U.S. government-have supported oil companies, miners, loggers, and pharmaceutical companies on indigenous lands, and in many of those countries (Bolivia, Peru, Ecuador, Guyana, Indonesia, and Papua New Guinea, among others) private concessions sanctioned by governments have provoked considerable violence. Each of the large conservation NGOs has close financial and political ties to the governments ... and is reluctant to oppose them. This has given rise to the ironic observation that the large international NGOs are allying themselves with forces that are destroying the world's remaining ecosystems. ${ }^{47}$

Yet, some interaction with national and local government is critical to successful private environmental conservation. ${ }^{48}$ Even assuming a perfect NGO or an entirely ecosystem-benevolent corporation, governments are needed to "implement the policies that result in progressive change." 49

Sanderson acknowledges the impotence of leaving NGOs to be environmental watchdogs: "If conservationists simply criticize development and poverty alleviation without offering realistic alternatives, they will consign themselves to perpetual irrelevance." ${ }^{\text {T0 }}$ The difficulty in garnering concrete information about the projected plan for Tierra del Fuego perhaps undermines the validation of NGOs through their ability to merely illuminate environmental conservation strategies and promote transparency in the environmentalist regime.

While he attributes at least some value to "wildlife health surveillance," 11 Sanderson's main focus is an attempt at a quantifiable agenda for action. Thus, his argument can be viewed as predominantly critical toward NGOs for a lack of involvement in the political realm, rather than as a futile attack on govern-

47. Id. at 26.

48. See Marissa A. Pagnani, Note: Environmental NGOs and the Fate of the Traditional NationState, 15 Geo. Int'L Envtl. L. Rev. 791, 807 (2003).

49. Id.

50. Sanderson, supra note 1, at 168.

51. Id. at 170 . 
ment corruption. Case studies support his proposition. ${ }^{52}$ For example, William Weeks, former vice president of The Nature Conservancy (TNC), explains the importance of NGOs maintaining partnership with government and allowing for effective communication:

To the greatest degree possible, government officials are considered and treated as colleagues and partners. That inclination extends to the way the organization handles its differences with government, it seldom criticizes government action or officials. Its style is to differ privately, in the presence of government officials. To prepare for a meeting to discuss differences with government representatives, TNC typically makes a serious effort to develop a course of action the government could follow that would resolve the points of disagreement in a manner that satisfied the objectives of both sides. ${ }^{53}$

Government can also subsidize environmentally responsible behavior, and its adoption of environmental ideals is essential to real conservation success..$^{54}$ Good private conservation involves government, and, consequently, NGOs may require some political sway to be effective. In fact, NGOs and other nonstate actors may seek a "nation-like existence" in order to achieve political influence ${ }^{55}$ by binding members through a sense of common purpose to effect world change. ${ }^{56}$

Thus far in the skeletal plan for Tierra del Fuego, no mention has been made of the Chilean government beyond the inclusion of governmental representatives on the advisory board. Although the land is privately owned, ignoring Chile as a state could prove detrimental to the WCS's effort. When American multimillionaire Douglas Tompkins bought hundreds of thousands of acres of Chilean forest for a reserve, the purchase led to publicized conflicts with local officials and the Chilean Congress. ${ }^{57}$ Consequently, local Chileans may be suspi-

52. See W. William Weeks, Beyond the Ark: Tools for an Ecosystem Approach to ConservaTION (1997).

53. Id. at 19.

54. See id. at 131-32.

55. Pagnani, supra note 48 , at 800.

56. See Max Weber's definition of "nation" in Max Weber, The Nation, in NAtionalism 21 (John Hutchinson \& Anthony D. Smith eds., 1994).

57. Rohter, supra note 6. 
cious of foreign-led conservation efforts. ${ }^{58}$ However, political tension in the Southern Cone is well-recognized, and reports indicate that the WCS will both take into account "potential political pitfalls" and actively seek involvement with the Chilean government. ${ }^{59}$ Additionally, the WCS hopes that the on-site administration of the reserve will balance political tension with the need for governmental involvement. ${ }^{61}$ Despite Sanderson's assertion that conservation projects "will often have to be routed around governments rather than through them," he recognizes the importance of political consciousness to environmental protection.

\section{NGO Global Alliances}

Sanderson's support of government involvement in private conservation implies a need for political savvy and cooperation with political entities. But Sanderson wants additional political structure within the private sector itself, emphasizing the organization of NGO activity through global conservation alliances. ${ }^{62}$ Though governments seem superficially better situated to embrace globalization through international institutions already in place, Sanderson asserts that nongovernmental groups can and should take up this tactic. ${ }^{63} \mathrm{He}$ states, "Conservation organizations are starting to collaborate more effectively, but they need a strong agenda and a higher degree of mutual trust." ${ }^{\prime \prime}$

In Tierra del Fuego, this idea of global alliance in the private realm is demonstrated by the work of TNC, another well-reputed environmental NGO, which conducted an ecological survey of the land in $2002 .^{65}$ The study was apparently very influential in the decision by Goldman Sachs to donate the land for conservation rather than exploit its old growth forests for logging, and the Charitable Fund maintained contact with TNC throughout the following year for "advice on managing the property." ${ }^{66}$ As Goldman Sachs eventually chose the WCS rather than TNC as the actual recipient of these lands, it remains to be seen whether TNC will continue to be involved with the preserve. However,

58. Id.

59. Id.

60. Id.

61. Sanderson, supra note 1 , at 169.

62. See id. at 172.

63. See id.

64. Id.

65. Press Release, Wildlife Conservation Society, supra note 27.

66. Id. 
TNC is well-experienced in using ecotourism as a means of conservation management and shares its knowledge through publicly available literature. ${ }^{67}$ The benefit of this experience could be enhanced in Tierra del Fuego by allowing TNC to be expressly involved in implementing ecotourism on the island.

Elsewhere, NGO cooperation has been useful in promoting effective conservation. For example, the Monteverde Conservation League in Costa Rica utilizes numerous partnerships with surrounding local schools, cooperatives, corporations, and other NGOs. ${ }^{68}$ Also, the Indonesia Biodiversity Foundation (KEHATI) has created an endowment for biodiversity to achieve financial stability among NGOs in Indonesia in the face of political and economic turmoil. ${ }^{69}$ Among KEHATI's main objectives, as stated in its by-laws, is the goal to "initiate and promote national, regional and international cooperation among nongovernmental organizations." found across Asia, in Latin America, and in Africa. ${ }^{71}$ They remain distinct from solitary NGOs because they "mobilize and facilitate the transfer of financial resources to NGOs and other more informal associations while also convening stakeholders around critical issues and building the capacity of civil society." $/ 2$ In Ethiopia, for example, an NGO called ENDA (Ethiopia Environmental Development Action) organized a "Forum for Environment," to connect people from all different sectors in an environmentally centered network. ${ }^{73}$ The Ethiopia Heritage Trust maintains contacts and joint activities with both Ethiopian Wildlife and the Natural History Society. ${ }^{74}$

Though many of these alliances are within one nation's boundaries, like the WCS and TNC in the United States, it seems that private sector groups are in many cases actively sharing information rather than pursuing private glory through success, which indicates a stronger focus on the environment itself and

67. See, e.g., 1 Andy Drumm \& Alan Moore, Ecotourism Development: A Manual for Conservation Planners and Manacers (2d ed. 2005), http:/www.nature.org/aboutus/travel/ecotourism/ files/ecotourism_development_vol1_eng_2nd_edition.pdf.

68. Sturm, supra note 12, at 255.

69. Sarah Maxim et al., Building an Endowment for Biodiversity Conservation in IndoNESIA iv (2004), http:/www.synergos.org/globalphilanthropy/04/asiafinancingkehati.pdf.

70. Id. at 21 .

71. Id. at ii.

72. Id.

73. Sandra Dierig, Urban Environmental Management in Addis Ababa: Problems, Policies, Perspectives, and the Role of NGOs 143 (1999).

74. Id. at 129. 
"brands the activity of conservation itself rather than individual organizations." 75 Also, these networks may allow for NGOs to have a greater force and political influence in the campaign for conservation. ${ }^{76}$

B. "The Politics of Place"

\section{Biodiversity Hotspots}

The necessity of scientific knowledge and research is a recurring theme in The Future of Conservation. Sanderson encourages science-based conservation in the private sector and includes "wildlife health surveillance," "tracking the state of the wild," and "scientific sustainability audits" as key elements in his New Conservation Agenda. ${ }^{77}$ Indeed, publicity of the Tierra del Fuego Reserve has largely centered on the ecological characteristics of the land and the scientific surveys conducted by TNC and the Trillium Corporation during the 1990s, when the land was being developed for commercial logging. ${ }^{78}$

Government-based conservation projects often look to private groups for scientific research to supplement their management strategies. ${ }^{79}$ Environmental NGOs typically place great emphasis on science and have demonstrated a high aptitude for conducting surveys and creating databases. In Costa Rica, for example, NGOs have been influential in publishing scientific and ecological assessments of the state of biodiversity in the region. ${ }^{80}$ In 1982, the Centro Cientifico Tropical (Tropical Science Center) published a complete analysis of environmental conditions (Costa Rica Country Environmental Profile-A Field Study) ${ }^{81}$ Similarly, in 1988 , the Neotropical Foundation published a study on the relationship between socioeconomic benefits and environmental protection. ${ }^{82}$ Inadequate surveillance of conservation efforts has been a problem in Costa Rica, so NGO help is greatly needed ${ }^{83}$ Similarly, Costa Rican NGOs, rec-

75. Sanderson, supra note 1 , at 172.

76. See Dierig, supra note 73, at 145.

77. Sanderson, supra note 1, at 171-72.

78. Rohter, supra note 6.

79. Jane H. Bock \& Katy Human, NGOs and the Protection of Biodiversity: The Ecologists' Views, 13 Colo. J. Int'l Envtr. L. \& Pol'y 167, 172 (2002).

80. Sturm, supra note 12.

81. Id. at 251 .

82. Id.

83. Id. at 243. 
ognized for their remarkable success in preserving the nation's tropical rainforests, place emphasis on education, particularly of young people, about the environment and about environmental threats facing the forests and other ecosystems. $^{8+}$

Despite the apparent success of some science-based efforts, NGOs are sometimes criticized for spending too much time generating data and not enough time actively protecting the ecosystems they monitor. ${ }^{85}$ "IT] $\mathrm{T}$ he presumption that biological sciences should be the sole guiding principle for biodiversity conservation in protected natural areas" has in many instances caused dissonance between NGOs' policies and the needs of indigenous people, leading to ineffective attempts at conservation. ${ }^{86}$ Though Sanderson certainly does not discount the value of surveillance and the importance of informing society about environmental issues, he links science to sustainable development, asserting that "the international community will benefit from clear scientific assessment of various human possibilities in an increasingly fragile biosphere." ${ }^{87}$ In this sense, his conservation agenda challenges NGOs to shift the focus of their research to a government-based approach and to use their hard science skills to deal with sociological issues.

The Nature Conservancy's survey revealed an abundance of biodiversity in Tierra del Fuego, showing it to be worthy of careful protection. ${ }^{88}$ The lands include rare old-growth lenga forests, as well as grasslands, meadows, snowcapped mountains, river systems, and an unusual and complex peat bog system covering one-third of the land. ${ }^{89}$ The land has been extensively studied from an ecological perspective, and is known to house at least seventy-seven species of birds, including the Magellanic woodpecker ${ }^{90}$ and over seven hundred plant species. ${ }^{91}$ Additionally, Tierra del Fuego is home to the charismatic guanaco, a South American relative of the camel, ${ }^{92}$ which migrates from the coast to the

84. Id. at 251 .

85. Chapin, supra note 46 , at 26.

86. Id.

87. Sanderson, supra note 1 , at 171.

88. See Press Release, Wildlife Conservation Society, supra note 27, at 2.

89. Id.

90. The Magellanic woodpecker is the largest of all woodpeckers, up to 35 centimeters long. Michael Bright, South America Revealed: A Wildlife Guide From Andes to Amazon 56-57 (2000).

91. Rohter, supra note 6.

92. See Bright, supra note 90 , at 48 . 
hills searching for food from plants. ${ }^{93}$ The guanaco, like a camel, spits at its enemies, and the species is a readily identifiable symbol of the area. ${ }^{9+}$

The globally significant ecology of Tierra del Fuego is also in great peril, justifying its specific protection in a worldwide conservation movement. The population of the guanaco has declined significantly in the last 500 years due to hunting, and currently shares a tenuous relationship with Chilean cattle and sheep farmers. Invasive species are a huge environmental problem on the island; these include sheep, which transmit disease to the guanaco, and beavers, whose dams interfere with natural water flow. ${ }^{95}$ However, the introduction of fish species, such as trout and salmon, are a major attraction for ecotourism and so could possibly be embraced by the conservation plans. The trees of the old-growth lenga and mixed sub-Antarctic forests, extremely precious to conservationists and Chileans, are also extremely delicate. ${ }^{96}$ Shallow topsoil and fierce winds cause them to grow horizontally, creating a unique but fragile ecological phenomenon. ${ }^{97}$

Apart from its wealth of biodiversity, as indicated by the TNC survey, Tierra del Fuego's appeal as "the ends of the earth"-the island is located at the southernmost tip of South America-likely made it a favorable target for the Goldman Sachs Charitable Fund, which, despite its altruistic goals, will certainly accrue some financial benefit from its choice of conserving "lands written about by Darwin." Sanderson's article discusses this "politics of place" 98 and the importance of conserving hotspots of biodiversity. ${ }^{99}$ Although certainly laudable, extreme focus on these isolated "wild places," particularly by the private sector, could ignore equally valuable, though less glamorous, terrains—such as urban environments. ${ }^{100}$

93. Rohter, supra note 6.

94. Id.

95. Id.

96. Id.

97. Id.

98. Sanderson, supra note 1 , at 169 . He states that "efforts need to be focused on the principal areas of conservation importance" and that "[t]hanks to more than a decade of analysis of "biodiversity hotspots,' 'critical ecoregions' and 'the last wild places,' the conservation community's threat assessments are pretty comprehensive." Id. at 169-70. At the very tip of South America, Tierra del Fuego is certainly one of these "last wild places," and its biodiversity has been assessed by The Nature Conservancy and advertised by the Wildlife Conservation Society, according to the Press Release, Wildlife Conservation Society, supra note 27.

99. Sanderson, supra note 1 , at 170.

100. For private sector challenges particular to urban environmental management, see DIERIC, supra note 73. 


\section{Embracing the World Heritage Site Concept Through Human-Centered}

\section{Conservation}

Interestingly, though, Sanderson next calls upon NGOs to embrace the World Heritage Site concept, established by the 1972 Convention for the Protection of the World Cultural and Natural Heritage. ${ }^{101}$ Though this convention seeks to protect "natural areas of outstanding universal value from the point of view of science, conservation, or natural beauty," 102 its primary purpose is to protect cultural heritage, reflecting a strongly anthropocentric view of conservation. Also, World Heritage Sites are completely dependant on governmental approval, ${ }^{103}$ so any private involvement in this particular program would again cast nonstate actors as only forecasters with no power to cause change. Advocating such a government-oriented program seems contrary to Sanderson's earlier criticism of international environmental conventions. ${ }^{104}$ He touts the World Heritage Sites as a small success in an "anemic official conservation agenda [that] has been shaped by international political and economic institutions designed for other purposes." ${ }^{105}$ However, his words are not intended for the parties directly involved in such failures, but for the private sector groups lurking in the background.

In the past, NGOs have demonstrated a tendency to work against the poor rural communities whose environments they seek to preserve, by halting important and locally sanctioned development in favor of "preserving" traditional methods and technology. ${ }^{106}$ In many cases, "NGOs place the burden for conservation on the poor in the countries that have not consumed their resources." 107 Environmental groups in Namibia, Uganda, and India have prevented the construction of dams for hydroelectric power and irrigation. ${ }^{108}$ The Maya were moved off of their land for the Cockscomb Jaguar Preserve, although they had been living peaceably with the jaguars. ${ }^{109}$ Local populations, such as the African

101. Convention for the Protection of the World Cultural and Natural Heritage, Nov. 16, 1972, 27 U.S.T. 37, 1037 U.N.T.S. 151.

102. Id. art. 2.

103. Id. art. 11 (3) ("The inclusion of a property in the World Heritage List requires the consent of the State concerned.").

104. See Sanderson, supra note 1, at 163-66.

105. Id. at 164.

106. See Thomas R. DeGregori, NGO;, Transgenic Food, Globalization, and Conservation, 13 Colo. J. Int'L Envtl. L. \& Pol'y 115, 123 (2002).

107. Id.

108. Id. at 123-24.

109. Id. at 126-27. 
Maasai and the Kung in the Kalahari desert, have been displaced from agricultural activities and cattle grazing that were traditional among these peoples. ${ }^{110}$

Perhaps if environmental NGOs are to adopt a more human-oriented approach for ecosystem advocacy, they can abandon this unfavorable history and assume a more prominent and effectual role in preserving natural as well as cultural heritage. The concept of indigenous knowledge, or " $\mathrm{IK}$," has been increasingly endorsed in scientific literature as a necessary component of ecological conservation. ${ }^{111}$ But this potential has not been widely realized in the private sector, so its value remains largely speculative. KEHATI works to bring awareness of local indigenous knowledge and funds other environmental organizations to do the same. ${ }^{112}$ Though private sector conservation in Indonesia has been slow to develop, its network of NGOs has been somewhat successful in spite of the typically poor environmental conditions in Asia generally. ${ }^{113}$ Because of the WCS's longstanding history in Latin America, ${ }^{114}$ the organization is well-poised to consider the cultural heritage and indigenous knowledge of Tierra del Fuego. In addition, the ecological survey conducted by TNC was based in part on the knowledge of Chilean scientists, which could be included in a more expansive definition of IK as "a body of knowledge associated with a fixed territorial space for a considerably long period of time." 115

110. Id, at 124 .

111. See, e.g., Jude L. Fernando, Rethinking Sustainable Development: NGOs and Production of Indigenous Knowledge under the Condition of Postmodernity, 590 AnNals 54 (2003).

112. Damayati Buchori \& David Ardhian, Local Involvement in Emerging Democracy: A Case Study of Biodiversity Management in Indonesia, in Biodiversity, Sustainability and Human ComMUNITIEs, supra note 12 , at 275,282 . Updated information about KEHATI projects is available at Yayasan Kehati, http:/www.kehati.or.id, (last visited Apr. 5, 2005).

113. Buchori \& Ardhian, supra note 112, at 282.

114. Press Release, Wildlife Conservation Society, supra note 27, at 4.

115. Fernando, supra note 111, at 56; see also Bernhard Venema \& Hans van den Breemer, Natural Resource Management in Africa: Approaches, Constraints and Opportunities, in Towards Necotiated Co-management of Natural. Resources in Africa 1, 6-7 (Bernhard Venema \& Hans van der Breemer eds., 1999) (" $[G \mid$ reater attention should be given to locally derived technologies .... [F]armers spontaneously adopt new elements and ideas, which become part of their 'indigenous' knowledge. This was the case in Machakos, where roads, traffic and market forces led to information exchange that was beneficial for the adoption and improvement of soil and water conservation. A development strategy which rejects all non-indigenous farm technology is very unrealistic."). 


\section{Sustainable Development Through Ecotourism}

Sanderson upholds sustainable development as the crux of private sector conservation, yet this heavily loaded phrase has innumerable meanings within the environmental arena. ${ }^{116}$ Sanderson criticizes governmental institutions for equating sustainable development with poverty alleviation; ${ }^{17}$ this priority is evidenced by the evolution of international environmental conventions, which have gradually placed human concerns well above environmental protection. ${ }^{118}$ He likewise asserts that "the concept of 'sustainable development' has proven less a viable middle ground than an empty rhetorical vessel." 119 Such an accusation points to a prevailing definition of sustainable development as "development that meets the needs of the present generation without compromising the ability of future generations to meet their own needs." 120 This interpretation in turn invokes a balance between economic growth and conservation of natural resources. Such a balance becomes increasingly difficult if we accept the notion that "for the hungry and otherwise deprived ... the future is substantially a dayto-day continuation of a relatively unchanging past and a seemingly unchangeable present."121

Environmentalists typically plant themselves on the conservation end of the spectrum, leaving governments to fight (successfully) for economic development. But Sanderson also criticizes NGOs for failing to address poverty issues at all, and focuses his article primarily on the need to help the rural poor. ${ }^{122} \mathrm{He}$

116. See Michael Redclift, The Meaning of Sustainable Development, 23 Geoforum 395, 399 (1992).

117. Sanderson, supra note 1 , at 168.

118. See Stockholm Declaration of the United Nations Conference on the Human Environment, June 16, 1972, 11 I.L.M. 1416 (stating its purpose as "the preservation and enhancement of the human environment," it is commonly held as the birth of international environmental law (emphasis added)); Rio Declaration on Environment and Development, June 13, 1992, 31 I.L.M. 874. ("Human beings are at the center of concerns for sustainable development."); Johannesburg Declaration on Sustainable Development, Sept. 4, 2002, available at http:/www.un.org/esa/sustdev/ documents/WSSD_POI_PD/English/POI_PD.htm (reaffirming the "pillars of sustainable development-economic development, social development, and environmental protection").

119. Sanderson, supra note 1 , at 164.

120. World Comm'n on Env't \& Dev., Our Common Future, at 54, U.N. Doc. A/42/427 (Aug. 4, 1987).

121. Lakshman C. Guruswamy et al., International Environmental Law and World Order 1089 (2d. ed. 1999).

122. Sanderson, supra note 1 , at 169-70, 173. 
states " $[t]$ he acid test of a conservation organization should therefore be its connection to the field and its long-term commitment to working in partnership with those who need sustainability most: the long-forgotten rural poor of the fragile frontier." 123 Though NGOs have historically been deemed more effective than government at generating local involvement, Sanderson's argument is unique in that it so blatantly emphasizes predominance of anthropocentric issues rather than uncompromising protection of the ecosystem, a viewpoint traditionally assigned to the public sector. ${ }^{124}$

Such an emphasis is consistent, however, with successful NGO environmental management. ${ }^{125}$ In Tierra del Fuego, Sanderson's idea of sustainable development is embodied in a plan to promote ecotourism in the area. Ecotourism is likewise a controversial environmental issue. ${ }^{126}$ Ecotourism can be defined as "responsible travel to natural areas, which conserves the environment and improves the welfare of the local people." ${ }^{27}$ But its implementation is not always so grand, as negative impacts associated with mass tourism often can be detrimental to local environments. ${ }^{128}$

Even so, promotion and support of ecotourism has achieved great success in dealing with poverty, ${ }^{129}$ which is Sanderson's unexpected focus for future NGO efforts. Insofar as The Future of Conservation is a direct challenge to NGOs to use

\section{Id. at 169 .}

124. Id.

125. Tim O'Riordan and Susanne Stoll-Kleemann posit that good environmental protection involves local participation. Tim O'Riordan \& Susanne Stoll-Kleemann, Deliberative Democracy and Participatory Biodiversity, in Biodiversity, Sustainability and Human Communities 87 (Tim O'Riordan \& Susanne Stoll-Kleemann eds., 2002). This approach in turn requires that environmental organizations focus on the lives and livelihood of these local peoples; the case studies chosen by O'Riordan and Stoll-Kleemann serve to illustrate this concept, tracking conservation efforts in Costa Rica, South Africa, Brazil, Namibia, Germany, Finland, Estonia, Croatia, Indonesia, and the United States. Biodiversity, Sustainability and Human Communities, supra.

126. See Alexander C. O'Neill, What Globalization Means for Ecotourism: Managing Globalization's Impacts on Ecotourism in Developing Countries, 9 Ind. J. Global Legal Stud. 501 (2002).

127. Héctor Ceballos-Lascuráin, Introduction to 2 Ecotourism: A Guide for Planners and Managers 8 (Kreg Linberg et al. eds., 1998).

128. Ben G. Blount, Indigenous Peoples and the Uses and Abuses of Ecotourism, in ON Biocultural Diversity: Linking Lancuage, Knowledge, and the Environment 503, 507-08 (Luisa Maffi ed., 2001).

129. See Marla Kerr, Ecotourism: Alleviating the Negative Effects of Deforestation on Indigenous Peoples in Latin America, 14 Colo. J. INT'L EnvTL. L. \& PoL'y 335, 352-64 (2003) (arguing that "ecotourism can protect indigenous people by combating deforestation" and "by inviting indigenous people to participate and control ecotourism projects"). 
their ability of working intimately with local people to achieve a more governmental notion of sustainable development, its implementation through ecotourism in Tierra del Fuego could prove a viable plan of action. Private sector conservation in Costa Rica provides a useful example.

Nongovernmental organizations have received much publicity in Costa Rica by promoting sustainable development, with a particular emphasis on ecotourism. ${ }^{130}$ Costa Rica possesses significant biodiversity, especially in its tropical forests, which once covered a large portion of the country. ${ }^{131}$ These dense forest ecosystems are now largely depleted due to inadequately managed agricultural development, as well as pollution and invasive species. ${ }^{132}$ Despite mass advertisement as "Costa Rica-no artificial ingredients" by the Costa Rican Tourism Institute, the government has historically given preference to economic exploitation of the woodlands, and indigenous populations have been widely neglected in the public sector. ${ }^{133}$

In the private sector, strong and persuasive efforts are being made to alleviate resistance to environmental protection, by showing populations affected by preservation efforts how to make a living from the protection of biodiversity. ${ }^{134}$ NGO efforts are praised as "an excellent example of managed resource protection areas and the balance between conservation and ecotourism." 135 Two prominent NGO-managed reserves, the Reserva Biologica Bosque Nuboso Monteverde, established in 1950 by Friends of the Earth, and the Bosque Eterno de los Niños (Children's Eternal Rainforest), strive to exemplify sustainable use, incorporating farming practices and a limited amount of tourism. ${ }^{136}$ The Cooperativa de Santa Elena supports ecological farming in this area, especially by helping local farmers sell high-priced ecologically cultivated coffee to tourists from the United States and Germany. ${ }^{137}$ Similarly, the Centro de Artesania de Santa Elena $y$ Monteverde employs 120 local men and women to produce textile and wood souvenirs, creating new jobs and promoting emancipation of women. ${ }^{138}$

130. Id. at 354 .

131. Sturm, supra note 12, at 243.

132. Id.

133. Id. at 243-44.

134. Id.

135. Kerr, supra note 140 , at 353.

136. Sturm, supra note 12, at 252-57.

137. Id. at 255 .

138. Id. at 256 . 
The Red Costarricense Naturales (Costa Rican Natural Preserve Net) is comprised of fifty organizations, including the significant Centro Cientifico Tropical, and uses its esteem from local people and its ability to interact with governmental bodies to promote protective use of the environment and preserve vegetation by supporting nature reserves. ${ }^{139}$ The Consejo Nacional para Desarrollo Sustentable (National Council for Sustainable Development), mandated by executive decree but including business and nongovernmental representatives, works to build consensus among Costa Ricans concerning sustainable development. ${ }^{140}$

Success of these NGOs can be measured by the fact that 40 percent of income derived from tourism stays in Monteverde. ${ }^{1+1}$ About 12 percent of revenues remaining in the region are devoted to conservation and about 20 percent providing employee income. ${ }^{142}$ Twenty-five to thirty percent of working people are employed by the tourism industry, which is 5 percent of all jobs. ${ }^{1+3}$ A bout 56 percent of the income by tourism is directed to hotels and restaurants, which are 70 percent locally owned. ${ }^{144}$ Achieving similar results in Tierra del Fuego would likely categorize the preserve as a local success.

\section{Conclusions for Tierra del Fuego}

While the economic success of ecotourism in Costa Rica may be relatively easy to quantify, measuring the success of environmental conservation is an extremely difficult task. ${ }^{145}$ Though "a consensus is emerging that the environmental movement needs something akin to the generally accepted accounting principles that govern financial reporting," ${ }^{146}$ such a system would need to account for the immense complexity of ecosystems as well as complicated interactions with political and social structures. ${ }^{1+7}$ Sanderson calls for independent scientific sustainability audits to bring accountability to global conservation efforts, ${ }^{148}$ yet it is the lack of availability of such empirical assessment tools that

139. Id. at $250-52$.

140. Id.

141. Sturm, supra note 12, at 257.

142. Id.

143. Id.

144. Id.

145. Jon Christensen, Fiscal Accountability Concerns Come to Conservation, N.Y. Times, Nov. 5, 2002, at F2.

146. Id.

147. Id.

148. See Sanderson, supra note 1, at 172. 
makes the evaluation of any theory of environmental management difficult. TNC and the World Wildlife Fund are now undertaking environmental audits at The Cosumnes River Preserve in California and the Komodo National Park in Indonesia, as well as at other sites across the globe. ${ }^{199}$ Yet this effort is only just beginning, and assessment of new management strategies such as Sanderson's is limited to comparison and a few environmental case studies.

The Future of Conservation represents a unique view of private sector conservation that incorporates some relatively new and controversial methods for preserving biodiversity. Specifically, Sanderson encourages NGOs to embrace trends of governmental management, such as global political alliance and economically oriented sustainable development, while utilizing their skills at dealing with the local community and engaging in scientific research. Though conclusive valuations of any approach should be treated with caution, the apparent success of similar systems, particularly in Costa Rica, indicates that management plans focused on ecotourism, poverty alleviation, and cultural heritage are characteristic of private conservation success. Additionally, the reputation of the WCS, in relation to its ongoing work in South America, bodes well for the implementation of a corresponding plan in Tierra del Fuego. ${ }^{150}$

149. Christensen, supra note 156.

150. Mac Chapin declares, "WCS's South American program is perhaps the best of the lot, with a strong focus on community-level conservation, co-management of protected a reas with indigenous peoples, and sustainable community development." Chapin, supra note 46 , at 28 . 
